\title{
A FORMAÇÃO DE UMA CLIENTELA PREFERENCIAL NO DIREITO PENAL BRASILEIRO À LUZ DA CRIMINOLOGIA CRÍTICA
}

\author{
Bruna Gomes Müller* \\ Edson Vieira da Silva Filho**
}

SUMÁRIO: Introdução; 1.1 O direito na sociedade capitalista; 2 Criminologia crítica no Brasil; 3 O Estado patrimonialista e o Direito penal Brasileiro; Considerações finais; Referências.

RESUMO: Esse artigo tem como objetivo compreender, com base na Criminologia Crítica, as injustiças resultantes da seletividade do sistema penal brasileiro, tendo o materialismo histórico-dialético como pano de fundo. Para tanto, baseou-se em uma perspectiva interdisciplinar que concebe o direito não só como o resultado de uma correlação de forças sociais (classes e grupos sociais) existente em dado momento histórico, mas, também, de outras relações de poder presentes no Estado patrimonialista brasileiro. Assim, buscou-se compreender a sociedade brasileira e seu sistema penal utilizando-se o conceito de estamento sem, entretanto, esquecer que essa sociedade é uma sociedade de classes.

PALAVRAS-CHAVE: Criminologia Crítica; Estado Patrimonialista; Marxismo; Seletividade Penal.

\section{THE FORMATION OF PREFERENTIAL CLIENTS IN BRAZILIAN PENAL LAW FROM THE PERSPECTIVE OF CRITICAL CRIMINOLOGY}

ABSTRACT: Injustices based on the selectivity of the Brazilian Penal Law are investigated by Critical Criminology through the principles of Historical and Dialectical Materialism. Discussions are based on the interdisciplinary perspective which conceives Law not merely as the result of the co-relationship of social forces (social classes and groups) within a given historical period, but with other power relationships within the Brazilian patrimonial State. Brazilian society and its penal system are analyzed through the concept of property without discarding that the former is also a class society.

KEY WORDS: Critical criminology; Patrimonial state; Marxism; Penal selectivity.

\footnotetext{
Discente do curso de Direito da Faculdade de Direito do Sul de Minas. Pesquisadora dos grupos de pesquisa Razão Crítica e Justiça Penal (PPGD/FDSM) e Margens do Direito (PPGD/FDSM), Brasil.

E-mail: bruna.gmuller@outlook.com

* Pós-doutor pela Unisinos; Doutor em Direito, pela Unesa; Docente auxiliar da Faculdade de Direito do Sul de Minas, Membro do Núcleo Docente Estruturante e coordenador do grupo de pesquisa Razão Crítica e Justiça Penal (PPGD/FDSM), Brasil.
} 


\section{LA FORMACIÓN DE UNA CLIENTELA PREFERENCIAL EN EL DERECHO PENAL BRASILEÑO A LA LUZ DE LA CRIMINOLOGÍA CRÍTICA}

RESUMEN: En ese artículo se tiene como objetivo comprender, con base en la Criminología Crítica, las injusticias resultantes de la selectividad del Sistema Penal brasileño, teniendo el materialismo histórico-dialéctico como tela de juicio. Para tanto, se basó en una perspectiva interdisciplinar que concibe el Derecho no sólo como el resultado de una correlación de fuerzas sociales (clases y grupos sociales) existente en dado momento histórico, sino, también, de otras relaciones de poder presentes en el Estado patrimonialista brasileño. Así, se buscó comprender la sociedad brasileña y su Sistema Penal utilizándose el concepto de estamento sin, entretanto, olvidar que esa sociedad es una sociedad de clases.

PALABRAS CLAVE: Criminología Crítica; Estado Patrimonialista; Marxismo; Selectividad Penal.

\section{INTRODUÇÃO}

Em um Estado democrático de Direito, é fundamental que se garanta os direitos mínimos que assegurem a dignidade da pessoa humana. A Constituição Brasileira diz, expressamente, no seu artigo $1^{\circ}$ (Título I-Dos Princípios Fundamentais) o seguinte:

\footnotetext{
Art. $1^{\circ}$ A República Federativa do Brasil, formada pela união indissolúvel dos Estados e Municípios e do Distrito Federal, constitui-se em Estado Democrático de Direito e tem como fundamentos:

I -a soberania;

II -a cidadania;

III - a dignidade da pessoa humana;

IV - os valores sociais do trabalho e da livre iniciativa;

$\mathrm{V}$ - o pluralismo político.

Parágrafo único. Todo o poder emana do povo, que o exerce por meio de representantes eleitos ou diretamente, nos termos desta Constituição.
}

A efetividade jurídica imediata desse princípio constitucional não tem encontrado respaldo no que diz respeito à pessoa e à integridade física e moral dos presos do sistema penal brasileiro. De fato, esse sistema tem convivido com diversas 
violações de direitos humanos.

Sem abandonar a perspectiva de um direito de classes, buscou-se, na Criminologia Crítica, uma justificativa mais complexa, que explique a natureza do clientelismo que marca nosso direito penal. Isso porque, além da proteção de classes, que pode ser demonstrada com clareza, uma proteção mais difusa, que afeta a grupos que não se identificam necessariamente com classes sociais, é sentida no direito penal brasileiro. Para entender essa realidade, buscou-se em Faoro ${ }^{03}$ o conceito de estamento, para justificar o sistema de dominação que impregna a história brasileira, por meio do exercício de poder por grupos heterogêneos. Patrimonialismo estamental e estamento são categorias utilizadas por Faoro para descrever um conjunto de relações que teria permanecido na estrutura sociopolítica brasileira durante toda a sua formação até o final da década de $1950^{04}$.

O objetivo deste trabalho é compreender, com base na criminologia crítica, as questões metajurídicas que fomentam grande parte das injustiças e ilegitimidades do sistema penal brasileiro, contextualizando-o historicamente.

Para tanto se fez necessária a construção de um marco teórico marcado pela perspectiva interdisciplinar que concebe o direito como o resultado de uma correlação de forças sociais (classes e grupos sociais) existentes em dado momento histórico, sem, porém, pretender reduzir as relações conflitantes em nossas sociedades a relações de classes, desconsiderando-se outras relações de poder presentes no Estado patrimonialista brasileiro, compreendendo-o a partir de suas peculiaridades estruturais.

A modernidade tardia ${ }^{05}$ faz com que a compreensão da sociedade brasileira, em geral, e do sistema penal, em particular, num país crivado de contradições e marcado por uma incerteza ideológica pode ser buscada a partir do conceito de estamento.

Tomou-se, assim, como ponto de partida Pachukanis, expondo as

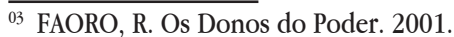

${ }^{04}$ ABREU, Maria Aparecida Azevedo. Raimundo Faoro. 2006, p. 171.

05 "Na periodização histórica de longa duração da modernidade do capital, [sugerida por Giovanni Alves], haveria uma primeira modernidade, que transcorreria do século XVI, primórdios do capitalismo moderno, ao fim do século XVIII e começo do século XIX. A primeira modernidade seria o período histórico do capitalismo comercial e capitalismo manufatureiro, onde as sociedades europeias ocidentais estariam ainda imersas em relações sociais tradicionais e sob a dominação de classe aristocrático-feudal, subsumidas à lógica do capital mercantil. A segunda modernidade do capital seria a modernidade da Primeira e Segunda Revolução Industrial, do surgimento da grande indústria, do modo de produção capitalista propriamente dito, da subsunção real do trabalho ao capital, da transição dolorosa e luminosa para a última modernidade do capital, a terceira modernidade. A terceira modernidade do capital é a modernidade tardia, a modernidade sem modernismo, ou a modernidade pós-modernista. A terceira modernidade é a modernidade do precário mundo do trabalho e da barbárie social. Enfim, entramos numa outra temporalidade histórica do capital, com impactos decisivos na objetividade e subjetividade da classe dos trabalhadores assalariados e do trabalho vivo". ALVES, Giovanni. Dimensões da Reestruturação Produtiva. 2007, p. 27, grifos do autor.
} 
contradições de um modelo social crivado de contradições de classes e em um segundo momento, ainda perseguindo uma construção histórica, tentou-se realinhar a teoria convencional marxista, ainda moderna e dicotômica por centrar-se na de uma polarização de classes - burguesia e proletariado. Uma análise que se limite a tais modelos de construção corre o risco de tornar-se ou manter-se polarizada e, reducionista, quando aplicada em uma região marginal ao sistema planetário (expressão de Zaffaroni ${ }^{06}$ ), levando a dinâmica do presente estudo a preocupar-se com a (extrema) complexidade em que se forma nosso modelo republicano onde a ré pública e a ré privada ainda se confundem sistematicamente.

\subsection{O DIREITO NA SOCIEDADE CAPITALISTA}

Desde o surgimento da sociedade capitalista até os dias atuais, as contradições que a caracterizam diversificaram-se e aprofundaram-se sem que se verificasse, contudo, sua descaracterização. Essa formação social possibilitou, como nunca antes na história da humanidade, um gigantesco desenvolvimento das forças produtivas. Apesar disto, bilhões ${ }^{07}$ de pessoas no mundo vivem em situação de pobreza e bilhões de trabalhadores sofrem as agruras do trabalho precarizado. A degradação das condições materiais de reprodução humana, inclusive nos países do denominado primeiro mundo, demonstra a incapacidade da sociedade burguesa de fornecer uma vida digna para todo ser humano. Essa degradação, segundo Alves ${ }^{08}$, "[...] é um traço indelével do esgotamento histórico de um modo planetário de controle do metabolismo social baseado na propriedade privada dos meios de produção social e divisão hierárquica do trabalho".

Os textos de Karl Marx (1818-1883) e Friedrich Engels (1820-1995) iniciaram no século XIX uma longa tradição de análise da sociedade capitalista. Desde os clássicos (Marx e Engels, Vladimir Ilitch Lenin (1870-1924), Leon Trótsky (18791940), Antonio Gramsci (1891-1937), Rosa Luxemburgo (1871-1919), Gueorgui Plekhanov (1856-1918), György Lukács (1885-1971), Evgeni Bronislávovich Pachukanis (1891-1937) etc.) até os contemporâneos (Ernest Mandel (1923-1995),

\footnotetext{
${ }^{06}$ Zaffaroni indica três sentidos para o termo "marginal": $\left(1{ }^{\circ}\right)$ a localização da América Latina na periferia do poder planetário, cujo vértice é ocupado pelos países centrais; $\left(2 .^{\circ}\right)$ a necessidade de se adotar a perspectiva dos fatos de poder latino-americanos próprios de sua relação de dependência com o poder central; e, $\left(3 .^{\circ}\right)$ a compreensão de que a grande maioria da população latino-americana marginalizada é objeto da violência do sistema penal. ZAFFARONI, E. R. En Busca de las Penas Perdidas. 1998, p. 170.

${ }^{07}$ Segundo o Relatório de Desenvolvimento Humano 2014, elaborado pelo PNUD (Programa das Nações Unidas para o Desenvolvimento), cerca de 2,2 bilhões de pessoas no mundo vivem atualmente, ou se encontram a ponto de estar, em situação de pobreza. A cifra representa mais de um terço da população global.

${ }^{08}$ ALVES, Giovanni. Terceira Modernidade do Capital, Crise de Civilização e Barbárie Social. 2011, p. 2.
} 
David Harvey (1935), István Mészáros (1930), Louis Althusser (1918-1990), Nicos Poulantzas (1936-1979) etc.), todos denunciaram a insustentabilidade em médio e longo prazo dessa sociedade.

Antes do aparecimento das sociedades de classes, cujo paradigma é a sociedade capitalista, não havia excedente econômico e o que era produzido destinava-se ao atendimento direto das necessidades mais imediatas da comunidade. As relações de produção eram relações de cooperação entre todos os indivíduos da comunidade. Os objetivos eram comuns e a divisão dos produtos do trabalho era coletiva. As relações de produção eram baseadas na propriedade coletiva dos meios de produção, com a terra ocupando papel central. Não existia ainda a da propriedade privada dos meios de produção, nem havia a exploração dos homens pelos homens. Com o início dessa exploração,

[...] surgiram as primeiras formas de sociedades de classes. Existem agora interesses antagônicos, inconciliáveis: de um lado os exploradores, de outro os explorados. Para manter a sua dominação, os primeiros criaram o Estado, que é o conjunto formado pelos funcionários públicos (a burocracia), a polícia, o exército e o Direito. ${ }^{99}$

Pela análise histórica das sociedades pré-capitalistas, verifica-se que o surgimento do direito está ligado historicamente à emergência das sociedades de classes e a complexificação das relações sociais e de troca entre os homens. Nas suas formas iniciais, o direito confunde-se com os padrões anteriores de organização social. Assim sendo, nas sociedades pré-capitalistas, o direito está organicamente interligado à religião, aos rituais e às tradições e à filosofia.

É no decorrer do surgimento, desenvolvimento e consolidação da ordem burguesa, que o direito constituir-se-á mais claramente com pretensão de cientificidade. É também nesta ordem que o campo do direito conhecerá um profundo e incomparável aperfeiçoamento em variadas direções e se expandirá para um conjunto amplo de relações sociais, sedimentando, regulando, consolidando juridicamente as condições de reprodução da sociedade burguesa. Nesse processo histórico, o direito desenvolver-se-á como um ramo específico do conhecimento humano, constituindo-se em uma instância diferenciada, responsável tanto pela elaboração conceitual das categorias, regras e princípios jurídicos, quanto pelas instituições e indivíduos especializados, responsáveis pela operacionalização desse

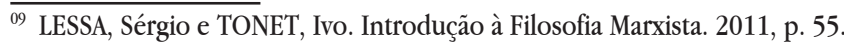


campo social ${ }^{10}$.

Assim sendo, situado no cerne da sociedade capitalista, o fenômeno jurídico é um dos seus componentes fundamentais e a sua compreensão é imprescindível para entender essa sociedade. Entretanto, o estudo do fenômeno jurídico, em geral, e da criminologia, em particular, utilizando o marxismo como ferramenta ainda é escasso nas nossas faculdades de direito. É por essa razão que se justifica estudar as contribuições de Pachukanis na compreensão do fenômeno jurídico.

Marx, Engels e diversos pensadores marxistas ${ }^{11}$ forneceram elementos fundamentais para a compreensão da história da humanidade, do capitalismo e do direito burguês. Mascaro afirma ${ }^{12}$ que Marx é o grande transformador da tradição do pensamento jusfilosófico e da filosofia política: ao mesmo tempo em que se debruça às bases, tocando em todos os fundamentos da filosofia política e do direito moderno, denuncia o profundo idealismo e caráter burguês de tais filosofias.

A famosa frase de Marx no prefácio da Contribuição à Crítica da Economia Política esboça a compreensão marxista do Estado e do direito:

A totalidade dessas relações de produção constitui a estrutura econômica da sociedade, a base real sobre a qual se eleva uma superestrutura jurídica e política e à qual correspondem formas sociais determinadas de consciência. O modo de produção da vida material condiciona o processo de vida social, política e intelectual. Não é a consciência dos homens que determina o seu ser; ao contrário, é o seu ser social que determina sua consciência ${ }^{13}$.

Para Lessa e Tonet, a exploração dos trabalhadores pela classe dominante só é possível

[...] com a criação de novos complexos sociais. Entre estes, os mais importantes foram o Estado e o Direito. O Estado é a organização da classe dominante em poder político. Tal poder apenas pode existir apoiando-se em um conjunto de instrumentos repressivos (exército, polícia, sistema penitenciário, funcionalismo público, leis etc.). Independentemente da forma que ele assuma e das formas de exercer o poder, segundo Marx, o Estado é, essencialmente, um instrumento de dominação de classe ${ }^{14}$.

\footnotetext{
${ }^{10}$ PEREIRA, Francisco. Karl Marx e o Direito. 2015, p. 55.

${ }^{11}$ Lênin, Lukács, Pachukanis, etc.

${ }^{12}$ MASCARO, Alysson Leandro. Introdução à Filosofia do Direito. 2002, p. 111.

${ }^{13}$ MARX, Karl. Contribuição à Crítica da Economia Política. 2008, p. 47.

${ }^{14}$ LESSA, Sérgio e TONET, Ivo. op. cit., p. 54.
} 
Atualmente, no campo do direito, o pensamento jurídico dominante é o juspositivismo. A compreensão do fenômeno jurídico para os juspositivistas é a do direito posto pelo Estado. O juspositivismo é uma perspectiva própria dos que assumem uma posição social e política conservadora. Como a reprodução da sociedade capitalista contemporânea funda-se, também, por meio do próprio direito positivo, considerá-lo o horizonte único da análise jurídica é manter exatamente a mesma estrutura que dá lastro à exploração social do presente. O juspositivismo tem em Hans Kelsen seu grande formulador ${ }^{15}$.

As correntes do pensamento jurídico que se abrem para enxergar o direito não apenas dentro dos limites do imposto normativamente pelo Estado são denominadas de não juspositivistas. Mascaro ${ }^{16}$ distingue os não juspositivistas em dois níveis: a) não juspositivistas em sentido estrito - aqueles que não se lastreiam no direito positivo e não utilizam a análise social marxista; b) não juspositivistas críticos - aqueles que apontam para os nexos do direito com as grandes estruturas sociais e adotam como método o marxismo.

Os não juspositivistas críticos dividem-se em duas vertentes em relação à compreensão do direito. A primeira vertente considera o direito como um instrumento neutro em princípio e, também, necessário à sociedade socialista. Essa vertente, abordada sob uma perspectiva institucionalista, possibilita por sua vez alguns desdobramentos que recaem tanto sobre o reformismo quanto à socialdemocracia. Um dos principais autores dessa vertente é o jurista soviético Stucka. Stucka via o direito como um fenômeno social que se modifica com a luta de classes. Sua reflexão tende a demonstrar que a base e o conteúdo do direito representam o interesse de classe. Dessa forma, a tomada do Estado pelo proletariado vai gerar, no período de transição ao socialismo, uma mudança no caráter classista do direito e a criação de um "direito proletário" ou "socialista". Stucka afirma que

[...] estaépoca de transiçãoé também umaépoca de predomínio de uma classe, classe esta constituída pela grande maioria até agora escravizada. Esta classe modifica todas as relações sociais e torna-as compreensíveis e evidentes para todos: introduz, em vez da artificial complexidade anterior, uma simplificação natural. Todavia, esta época pelo fato de se caracterizar por uma forma de Estado específica, o ordenamento soviético, mostra ser já um ordenamento social próprio, característico e que tem um direito proletário, soviético, específico ${ }^{17}$.

\footnotetext{
${ }_{15}$ MASCARO, Alysson Leandro. Introdução ao Estudo do Direito. 2013, p. 53-54.

${ }^{16}$ Ibidem, p. 60.

${ }^{17}$ STUCKA, Petr Ivanovich. Direito e Luta de Classes. 1988, p. 38, grifo do autor.
} 
A segunda vertente considera o direito como vinculado ao capitalismo. Essa vertente, que pode ser considerada como mais radical em relação à primeira, condena o direito por tomá-lo enquanto modo de estruturação institucional do próprio capitalismo. E a esta vertente, minoritária dentro do pensamento marxista, que se encontra vinculado o cientista social Pachukanis.

\section{CRIMINOLOGIA CRÍTICA NO BRASIL}

\subsection{INTRODUÇÃO}

Criminologia, etimologicamente, origina-se do latim crimino (crime) e do grego logos (estudo), significando o "estudo do crime"18. A criminologia, porém, não estuda apenas o crime, mas também a conjuntura social, a vítima, o infrator, o controle social do comportamento delitivo etc.

O termo "criminologia" tem a sua criação atribuída ao italiano Raffaele Garofalo (1851-1934), que o utilizou como título de sua principal obra ${ }^{19}$, escrita em 1885. Consta, porém, que tal termo já tinha sido usado anteriormente na França, pelo médico e antropólogo francês Paul Topinard (1830-1911).

A criminologia, ciência do "ser", é empírica e interdisciplinar. Empírica, pois seu objeto (crime, infrator, vítima e controle social do comportamento delitivo) está inserido no mundo real e não no mundo dos valores, como ocorre com o direito, que é uma ciência do "dever-ser", logo normativa e valorativa. Interdisciplinar, pois em sua metodologia utiliza diversas outras ciências, tais como a sociologia, a psicologia, o direito, a medicina legal etc.

$\mathrm{Na}$ criminologia, as teorias podem ser agrupadas em duas grandes vertentes: a) criminologia tradicional; b) criminologia crítica.

A criminologia tradicional, em suas diversas vertentes, busca identificar as causas do crime e as formas de preveni-lo, sempre em uma perspectiva antropocêntrica própria da leitura moderna da sociedade e a partir de desvios de comportamentos padrão construídos a partir de modelos ideais, pretensamente neutros e racionais. Já a criminologia crítica, além de investigar as causas do crime, pesquisa, também, a reação social, incorporando as instâncias formais de controle como fator criminógeno (as leis, a polícia, o Ministério Público e os Tribunais). Assim sendo, o principal marco da criminologia crítica está na leitura marxista da criminalidade e de

${ }^{18}$ Segundo Lyra e Araújo Júnior (1995, p. 3), "a palavra criminologia é hibridismo composto de raiz latina e desinência grega".

${ }_{19}$ GAROFALO, Raffaele. Criminologia. Torino, Fratelli Bocca, 1885. 
seu controle. Essa leitura se afasta das explicações antropocêntricas e migra a base teórica de fundamentação do controle do Estado para a reprodução do sistema de produção e distribuição de riquezas e das suas ideologias de sustentação dentro de um sistema de produção capitalista.

Segundo Santos ${ }^{20}$, a criminologia tradicional, com um discurso etiológico sobre criminalidade, tem papel de ciência auxiliar do direito penal e a criminologia crítica, com um discurso político sobre criminalização, tem papel de ciência crítica do direito penal, do Sistema de Justiça Criminal e das desigualdades sociais da relação capital/trabalho assalariado. Ao deslocar a culpa dos desvios para os indivíduos, absolve o sistema onde eles se inserem e o qual deve reproduzir.

A criminologia crítica se desenvolve por oposição à criminologia tradicional, estudada como realidade nascida de uma dogmática normativa, quase ontológica e explicada pelo método positivista de causas biológicas, psicológicas e ambientais. Ao contrário, a criminologia crítica é construída pela mudança do objeto de estudo e do método de estudo do objeto: o objeto é deslocado da criminalidade, como dado ontológico, para a criminalização, como realidade construída, mostrando o crime como qualidade atribuída a comportamentos ou pessoas pelo sistema de justiça criminal, que constitui a criminalidade por processos seletivos fundados em estereótipos, preconceitos e outras idiossincrasias pessoais, desencadeados por indicadores sociais negativos de marginalização, desemprego, pobreza, moradia em favelas etc.; o estudo do objeto não emprega o método etiológico das determinações causais de objetos naturais empregados pela criminologia tradicional, mas um duplo método adaptado à natureza de objetos sociais: o método interacionista de construção social do crime e da criminalidade, responsável pela mudança de foco do indivíduo para o sistema de justiça criminal, e o método dialético que insere a construção social do crime e da criminalidade no contexto da contradição capital/ trabalho assalariado, que define as instituições básicas das sociedades capitalistas ${ }^{21}$.

As principais escolas criminológicas cujas teorias pertencem à vertente da criminologia tradicional são: b) Teoria da Rotulação ou Labeling Approach Theory

\footnotetext{
${ }^{20}$ SANTOS, Juarez Cirino dos. Os Discursos sobre Crime e Criminalidade. 2013, p. $48-49$.

${ }^{21}$ SANTOS, Juarez Cirino dos. A Criminologia Crítica e a Reforma da Legislação Penal. 2005, p. 1-2.
} 


\title{
a) Escola Clássica ou Liberal22; b) Escola Positiva $^{23}$; c) Escolas Ecléticas ${ }^{24}$ (Escola
}

\author{
de Política Criminal ou Moderna Alemã, Terza Scuola Italiana ou Positivismo
}

\section{Crítico etc.). Em relação à vertente da criminologia crítica, as principais escolas}

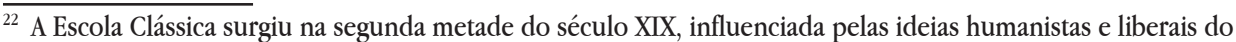
aristocrata italiano Cesare Bonesana (1738-1794), o Marquês de Beccaria. Esse jurista formulou os princípios da criminologia clássica, em "Dos Delitos e das Penas", de 1764, baseado nas teorias contratualistas de Thomas Hobbes (1588-1679) e Jean-Jacques Rousseau (1712-1778) e nas ideias de Montesquieu. Além de Beccaria, outros grandes nomes da Escola Clássica são os juristas italianos Gaetano Filangieri (1752,1788), Gian Domenico Romagnosi (1761-1835), Giovanni Carmignani (1768-1847), Pellegrino Rossi (1787-1848) e Francesco Carrara (1805-1888) e o filósofo alemão Paul Johann Anselm von Feuerbach (1775-1833). Os princípios fundamentais da Escola Clássica são: a) crime é um ente jurídico, o que significa que o crime é violação do direito, como exigência racional (e não como norma jurídica do direito positivo); b) responsabilidade penal fundada no livre-arbítrio, sendo a liberdade de querer um axioma fundamental para todo sistema do direito punitivo; c) a pena é retribuição jurídica e restabelecimento da ordem externa violada pelo delito; d) método lógico-abstrato no estudo do direito penal. (FRAGOSO, Heleno. Lições de Direito Penal. Parte Geral. 1995, p. 43-44). "A Criminologia da Escola Clássica tem como marco de filosofia política [...] as idéias liberais do contratualismo e, como modelo sociológico, o consenso. Este é o mesmo marco da Criminologia liberal denominada de organizacional, desenvolvida, principalmente, nos EUA e no Canadá, nos últimos trinta anos, e que tem o objetivo de, pragmaticamente, melhorar o sistema de controle social (policia, tribunais. serviços de assistência social, etc.) e formular, em definitivo, a Política Criminal através de investigações paliativas e proposições de reforma. É a Criminologia do "Gatopardismo": modificar as coisas para que nada seja modificado". (CASTRO, Lola Aniyar de. A Evolução da Teoria Criminológica e Avaliação de seu Estado Atual. 1982, p. 74).

${ }^{23}$ A Escola Positiva tem suas raízes no século XIX na Europa, influenciada pelas ideias desenvolvidas pelos fisiocratas e iluministas no século anterior. Em linhas gerais, a Escola Positiva teve três fases: a) antropológica - Cesare Lombroso (1835-1909), médico, considerado o pai da "Antropologia Criminal", publicou em 1876 o livro "O Homem Delinquente", que instaurou um período científico de estudos criminológicos; b) sociológica - Enrico Ferri (1856-1929), sociólogo, genro e discípulo de Lombroso, foi o criador da chamada "sociologia criminal". Para ele, a criminalidade derivava de fenômenos antropológicos, físicos e culturais; c) jurídica - Raffaele Garofalo recebeu influência do jusnaturalismo e buscou encontrar um conceito de delito natural. Os principais postulados da Escola Positiva são: a) a responsabilidade penal deriva não do fato cometido, mas do fato de se viver em sociedade; b) a pena é uma medida de defesa social; c) o crime não é um ato da vontade livre do indivíduo e sim um episódio de comportamento condicionado por fatores físicos, biológicos, antropológicos e sociais; d) método indutivo e experimental no estudo do direito penal. (SANTOS, Bartira Macedo de Miranda. As Ideias de Defesa Social no Sistema Penal Brasileiro. 2010, passim). "Aplicando às ciências sociais o método das ciências naturais, na busca estéril da unidade e universalidade do método, a Criminologia positivista orienta-se ora para o estudo do homem (Clínica), ora para o da sociedade (Sociologia Criminal: ecologismo, culturalismo, funcionalismo)". (CASTRO, Lola Aniyar de. A Evolução da Teoria Criminológica e Avaliação de seu Estado Atual. 1982, p. 77).

${ }^{24}$ As Escolas Ecléticas buscaram conciliar os preceitos das Escolas Clássica e Positiva. A Escola Moderna Alemã teve como principais expoentes o alemão Franz von Lizst (1851-1919), o belga Adolphe Prins (1845-1919) e o holandês Gerardus Antonius van Hamel (1842-1917). Os postulados da Escola Moderna Alemã foram: a) o método indutivo-experimental para a criminologia; b) a distinção entre imputáveis e inimputáveis (pena para os normais e medida de segurança para os perigosos); c) o crime como fenômeno humano-social e como fato jurídico; d) a função finalística da pena - prevenção especial; e) a eliminação ou substituição das penas privativas de liberdade de curta duração. A Terza Scuola Italiana, cujos expoentes foram Emanuele Carnevale (1861-1941), Bernardino Alimena (1861-1915) e Giovanni Battista Impallomeni (1846-1907), fixou os seguintes postulados criminológicos: a) distinção entre imputáveis e inimputáveis; b) responsabilidade moral baseada no determinismo (quem não tiver a capacidade de se levar pelos motivos deverá receber uma medida de segurança); c) crime como fenômeno social e individual; d) pena com caráter aflitivo, cuja finalidade é a defesa social. (POLAINO, Celso Gomes. Adequação da Pena. 2011, p. 57-60). 


\title{
são as seguintes: a) Criminologia Radical ou Criminologia Marxista ${ }^{25}$;ou Teoria
}

\author{
do Etiquetamento Social ${ }^{26}$; c) Criminologia Abolicionista ${ }^{27}$; d) Criminologia
}

Minimalista $^{28}$; e) Criminologia Neo-Realista ${ }^{29}$; f) Criminologia Cautelar ${ }^{30}$.

${ }^{25}$ A Criminologia Radical ou Criminologia Marxista nasce, a partir da década de 1960, após as contribuições científicas da psicanálise, da antropologia e da sociologia sobre a questão criminal. Tal criminologia surge mais diretamente da correlação do materialismo histórico (já explorado por Willen Bonger (18761940), Pachukanis e Georg Rusche (1900-1950)) com o interacionismo simbólico (perspectiva teórica que possibilita a compreensão do modo como os indivíduos interpretam os objetos e as outras pessoas com as quais interagem e como tal processo de interpretação conduz o comportamento individual em situações específicas). (LEMOS, Clécio José Morandi de Assis. Sistema Penal como Instrumento Proletário. 2013, p. 68). Rusche e Otto Kircheimer (1905-1965) publicaram em 1939, nos Estados Unidos, a obra "Punição e Estrutura Social" (RUSCHE, Georg e KIRCHHEIMER, Otto. Punição e Estrutura Social. 2004), sendo reconhecida como a primeira obra a incorporar o materialismo histórico na análise criminológica. (LEMOS, Clécio José Morandi de Assis. Sistema Penal como Instrumento Proletário. 2013, p. 66). A obra "The New Criminology: For a Social Theory of Deviance" (1973), dos autores Ian Taylor (1944-2001), Willian Stewart Jock Young (1942-2001) e Paul Walton, foi uma das pioneiras na construção das bases da Criminologia Radical ou Marxista. Segundo Santos, esse texto "é um dos primeiros estudos sistemáticos do desenvolvimento da teoria criminológica sob um método dialético, aplicando categorias do materialismo-dialético". (SANTOS, Juarez Cirino dos. A Criminologia Radical. 2008, p. 5).

${ }^{26}$ A Teoria da Rotulação surgiu nos anos 60, nos Estados Unidos, e seus principais expoentes foram Erving Goffman (1922-1982) e Howard Becker (1928). Segundo essa teoria, a criminalidade é vista não como uma "qualidade" da conduta humana, mas como uma consequência de um processo em que se atribui tal "qualidade" (estigmatização). A Teoria da Rotulação objetivou demonstrar "como o desvio não é algo que precede as definições e as reações sociais, mas uma realidade construída mediante as definições e as reações, e que através delas adquire a qualidade desviante ou criminosa. Deste ponto de vista, a criminalidade não é, portanto, uma qualidade ontológica, mas um status social construído através de processos (informais e formais) de definição e mecanismos (informais e formais) de reação." (BARATTA, A. Criminologia Crítica e Crítica do Direito Penal. 1999, p. 118).

${ }^{27}$ A Escola Abolicionista, cujas origens são atribuídas ao professor italiano Fillipo Gramatica, constituiu-se em uma forte reação humanitária aos horrores presenciados pelo mundo na época da Segunda Guerra Mundial. Os juristas dessa escola defendiam a perda de legitimidade do poder punitivo exercido pelo sistema penal vigente, devendo o mesmo, então, ser abolido e substituído por outros modelos de solução de conflito. Tal conclusão fundou-se em severas críticas dirigidas ao Direito Penal, visto como um sistema ineficaz e cruel. (PEREIRA, Henrique Viana e MAGALHÃES, Rodrigo Almeida. A Influência da Economia no Direito Penal. 2012).

${ }^{28}$ A Criminologia Minimalista, conhecida como Direito Penal Mínimo, foi desenvolvida pela venezuelana Lola Rebeca Aniyar Sananes de Castro (1937-2015) e o italiano Alessandro Baratta (1933-2002). O Direito Penal Mínimo assenta-se em dois fundamentos. O primeiro postula que a legislação penal deve ter um conteúdo mínimo visando garantir os direitos humanos e liberdades individuais, em defesa dos pobres e contra excessos de órgãos do Estado ou privados ou mesmo da vítima. O segundo exige a limitação do Direito Penal, por ser esse Direito um instrumento da minoria dominante. (LIMA, Odilardo Gonçalves. Estrutura Constitucional da Segurança Pública no Brasil. 2005, p.48).

${ }^{29}$ A Criminologia Neo-Realista defende que o objeto de estudo da Criminologia Crítica sejam as causas e as circunstâncias do delito, delatando as injustiças presentes no sistema de controle social.

${ }^{30}$ A Criminologia Cautelar é uma teoria criminológica proposta pelo jurista argentino Eugenio Raúl Zaffaroni (1940), a partir de sua obra "A Palavra dos Mortos", em contraposição à Criminologia Midiática. "A criminologia midiática cria a realidade de um mundo de pessoas decentes frente a uma massa de criminosos, identificada através de estereótipos que configuram um eles separado do resto da sociedade, por ser um conjunto de diferentes e maus. O eles da criminologia midiática incomodam, impedem de dormir com as portas e janelas abertas, perturbam as férias, ameaçam as crianças, sujam por todos os lados e por isso devem ser separados da sociedade, para deixar-nos viver tranquilos, sem medos, para resolver todos os nossos problemas. Para tanto, é necessário que a polícia nos proteja de suas ciladas perversas, sem qualquer obstáculo nem limite, porque nós somos limpos, puros e imaculados". (ZAFFARONI, Eugenio Raúl. A Palavra dos Mortos. 2012. p. 307). 


\subsection{RECEPÇÃO DA CRIMINOLOGIA NO BRASIL}

No Brasil, a recepção da criminologia começa nas últimas décadas do século XIX. Nessa época, a Faculdade de Direito do Recife (fundada em 1827 na cidade de Olinda e transferida para Recife em 1854) e a Faculdade de Medicina da Bahia (fundada em 1808) eram os principais centros irradiadores do pensamento criminológico no Brasil. Na Faculdade de Medicina da Bahia, a pesquisa se concentrava na perícia médico-legal e nos estudos antropológicos raciais. Por outro lado, a Escola de Direito do Recife passou a defender a legitimação científica do saber jurídico e o seu afastamento das ciências humanas. Segundo Alvarez,

diversos historiadores do direito penal consideram João Vieira de Araújo (1844-1922), professor da Faculdade de Direito do Recife, o primeiro autor a se mostrar informado a respeito das novas teorias criminais, ao comentar as ideias de Lombroso em suas aulas na Faculdade do Recife e também em textos sobre a legislação criminal do Império ${ }^{31}$.

Por outro lado, outros autores defendem que a recepção da criminologia no Brasil começou com o sergipano Tobias Barreto de Meneses ${ }^{32}$ (1839-1889), que, em 1884, no seu livro "Menores e Loucos em Direito Criminal", fez referências ao "O Homem"33. Tobias Barreto foi pioneiro nas críticas às ideias de Lombroso, ao contrário de seus contemporâneos. O jurista sergipano reconhecia o valor da obra de Lombroso. No entanto, criticava o excesso dos determinismos e o biologismo a que se estava tornando o trato do criminoso.

[...] importa reconhecer que o auctor alargou de mais as suas vistas e é excessivo nas suas apreciações. Tudo tem seus limites. O conhecimento exacto do criminoso não se compõe somente de dados psychologicos, fornecidos pela observação interna, directa ou indirecta; mas é igualmente certo que não se compõe só de dados craniométricos, dynamométricos, ophtalmoscópicos e todos os mais epithetos sesquipedaes, de que sòe usar a technologia medical. Ninguém, mais do que eu, está sempre disposto a reformar, a abandonar mesmo, como

\footnotetext{
${ }^{31}$ ALVAREZ, Marcos César. A Criminologia no Brasil ou Como Tratar Desigualmente os Desiguais. 2002, p. 682683.

32 Tobias foi o líder da Escola do Recife, movimento intelectual poético, crítico, filosófico, sociológico, folclórico e jurídico que floresceu na segunda metade do século XIX na Faculdade de Direito do Recife (hoje Faculdade de Direito da Universidade Federal de Pernambuco - UFPE).

33 ALVAREZ, Marcos César. A Criminologia no Brasil ou Como Tratar Desigualmente os Desiguais. 2002, p. 683.
} 
imprestáveis, as opiniões mais queridas, quando recahe sobre ellas qualquer suspeita de erro. Porém quero ver razões que me convençam. Não sou tão exigente, como David Hume, que aconselhava, como já disse, se mettesse no fogo todo o qualquer livro que não tratasse de factos observados ou de números, porque, fora disto, só podia encarar, - no seu parecer, - sophistica e rabulice. Ainda creio na lógica, operando sobre dados empíricos e podendo fazê-los decuplamente render. Mas não admitto de bom grado que, em nome desta ou daquella sciencia, levantem-se hypotheses, se não de todo gratuitas, ao menos, actualmente, impossiveis de verificar, e, como taes, incapazes de nutrir um espirito pouco affeito a se deixar illudir por phrases retumbantes ${ }^{34}$.

Silvio Vasconcelos da Silveira Ramos Romero (1851-1914), amigo de Tobias Barreto, membro da Escola do Recife, não possui uma obra extensa sobre criminologia. Seus estudos criminológicos foram reunidos pelo jurista Roberto Lyra (1902-1982) em "A obra de Sylvio Romero em Direito Criminal". Nessa obra, Silvio Romero concorda com a teoria filosófica evolucionista aplicada ao direito, mas não com seus métodos. Ao contrário de Tobias Barreto que, em sua concepção sobre a relação do direito com as ciências sociais, negava a possibilidade de uma ciência geral dos fenômenos sociais, Silvio Romero dizia que "o direito pode e deve ser estudado cientificamente, porque é um fenômeno sociológico, porque é uma das criações fundamentais da humanidade, cujo estudo constitui o amplo objeto da sociologia" ${ }^{35}$. Silvio Romero

aceitava a tese do "criminoso nato", porém não com a instrumentalidade apresentada por Lombroso. Em seu entendimento, a índole do "criminoso nato" situava-se entre a loucura e o atavismo. Neste esteio caberia a distinção entre o criminoso e o selvagem, negando, desse modo, a tese lombrosiana de uma criminalidade atávica comum aos selvagens ${ }^{36}$.

O jurista cearense Clóvis Bevilácqua (1859-1944), membro da Escola do Recife, pai do Código Civil Brasileiro de 1916, publicou no ano de 1896 sua primeira obra sobre criminologia, denominada "Criminologia e Direito". Nessa obra, Clóvis Bevilácqua analisa a criminalidade no Estado do Ceará no último quartel do século

\footnotetext{
${ }_{34}$ BARRETO, Tobias. Menores e Loucos em Direito Criminal. 2003, p 66-67, grifo do autor.

35 LYRA, Roberto (Org.). A Obra de Sylvio Romero em Criminologia e Direito Criminal. 1951, p. 39.

36 CYPRESTE, Artur Dalla. Crime e Trabalho no Brasil. 2010, p. 48-49.
} 
XIX, examinando primeiro a noção de crime. Para Bevilácqua,

a idéa de [considerar o crime] como um producto da sobrevivencia da vida selvagem, como um phenomeno bem característico de atavismo, que foi o poncto de partida dessa brilhante e numerosa eschola italiana, que tem por chefes Lombroso, Ferri, Garofalo, Marro, Fioretti, parece ter feito seu tempo ${ }^{37}$.

Bevilácqua, apesar de admirar a escola de criminologia italiana, criticava sua interpretação do crime. Em suas palavras:

Si vejo muita verdade nas três ordens de factores do crime, os physicos, os anthropológicos e os sociaes, tão profundamente estudados por Ferri; si admiro as pacientes observações de Lombroso e Marro, as vistas ousadas, quase geniaes do primeiro, e as deducções lealmente rigorosas do segundo; si applaudo as hábeis applicações da theoria do direito como as sabe fazer Garofalo; não posso desconhecer que há muita cousa a refazer, que muitas illações foram precipitadamente tiradas e que o caminho seguido nem sempre foi o mais conveniente. Não me proponho a fazer uma crítica detalhada da eschola, mas, para fundamentar o que acabo de avançar, limitar-me-ei a lembrar que, procurando interpretar o crime mais biológica do que socialmente, por mais que investiguem, nunca nos poderão dar uma idea exacta e completa delle ${ }^{38}$.

Euclides da Cunha (1866-1909), engenheiro, positivista, antimonarquista e abolicionista, com uma visão progressista da história, foi repórter de O Estado de São Paulo, acompanhando a luta de Canudos, em 1897. Segundo Roberto Lyra, Euclydes da Cunha "foi o criador de nossa Sociologia Criminal" 39 . Em toda a sua obra, principalmente em "Os Sertões", o fenômeno do crime é abordado de forma sociológica.

Raimundo Nina Rodrigues (1862-1906), médico e antropólogo maranhense, foi o fundador da antropologia criminal brasileira, um dos receptores das ideias de Lombroso no Brasil e o pioneiro nos estudos sobre a cultura negra no país. Segundo Schwarcz,

\footnotetext{
${ }_{37}$ BEVILÁCQUA, Clóvis. Criminologia e Direito. 1896, p. 53.

${ }^{38}$ BEVILÁCQUA, Clóvis. Criminologia e Direito. 1896, p. 58.

${ }^{39}$ LYRA, Roberto. Novo Direito Penal. 1980, p. 81.
} 
Nina Rodrigues legou uma imagem paradoxal. A despeito de ser considerado - a partir da publicação de obras como Africanos no Brasil e Animismo fetichista - como o primeiro antropólogo brasileiro a tratar de temas, hoje conhecidos, como "raciais", ele é também considerado um autor maldito; reconhecido como aquele que tratou de defender - e teorizar - as diferenças ontológicas existentes entre as diversas raças no Brasil, e em especial por considerar a mestiçagem como sinal de degenerescência ${ }^{40}$.

Ao contrário dos juristas da Escola do Recife que acomodavam modelos teóricos diversos - especialmente Tobias Barreto e Silvio Romero - Nina Rodrigues negava o pressuposto do evolucionismo social de que a "perfectibilidade" era possível e presente em todas as "raças". Além do mais, ao conferir às raças o estatuto de realidades estanques e ontológicas, passou a advogar que toda mistura de espécies era sinônimo de degeneração $0^{41}$.

Nina Rodrigues contribuiu para o desenvolvimento da antropologia, da medicina legal, da psiquiatria e da criminologia no Brasil. Sua trajetória confunde-se como próprio processo de legitimação social e científica da medicina legal.

Nina Rodrigues questionava a igualdade na implementação da lei penal. Segundo ele, as "raças inferiores" não possuíam capacidade para guiarem-se livremente. Com essa afirmação, argumentava contra o livre arbítrio e pedia uma reformulação das leis penais.

Júlio Afrânio Peixoto (1876-1947), médico, político, professor, crítico literário, ensaísta, romancista e historiador baiano, foi o principal criminologista da primeira metade do século XX. Escreveu diversas obras jurídicas, influenciando o pensamento jurídico no Brasil até os dias atuais. Sua obra "Criminologia" (1933) tornou-se o manual dessa disciplina nas universidades. Afrânio Peixoto relacionava a criminalidade, em geral, e a das mulheres, em particular, ao mau funcionamento do sistema endócrino. Em sua obra "Novos Rumos da Medicina Legal", afirma que

o homem está, pela fisiologia contemporanea, reduzido a um armario de glandulas. E o que essas glandulas produzem, suas inter-ações humorais, é que fazem a personalidade. [...] chegamos ao determinismo endocrinico. Virtude e vicio, alegria e magua, inteligencia ou cretinismo, normal ou invertido,

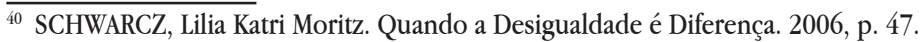

${ }^{41}$ Ibidem, p. 48.
} 
honesto ou criminoso, sceptico ou descrente, revoltado ou pacifico, gordo ou magro, alto ou baixo, calvo ou peludo, patriota ou cosmopolita, capitalista-burguês ou proletariomarxista, tudo são mais ou menos tais e tais sucos, somados, contrariados, deficientes, anulados, sobreexcedentes. É a onipotência tiranica dos hormonios ${ }^{42}$.

Inúmeros outros juristas e/ou médicos criminalistas, ao longo da Primeira República, passam, também, a divulgar as novas abordagens "científicas" acerca do crime e do criminoso: José Tavares Bastos (1813-1893), Paulo Egídio de Oliveira Carvalho (1842-1906), José Higino Duarte Pereira (1847-1901), Francisco José Viveiros de Castro (1862-1906), Esmeraldino Bandeira (1865-1928), Raimundo Pontes de Miranda (1868-1929), Cândido Mota (1870-1942), Antonio Evaristo de Moraes (1871-1939), Luiz Frederico Sauerbronn Carpenter (1876-1957), Aurelino de Araújo Leal (1877-1924), Antonio Moniz Sodré de Aragão (1881-1940), José Gabriel de Lemos Brito (1886-1963), Joaquim Pimenta (1886-1963) e Júlio Pires PortoCarrero (1887-1937) entre outros, publicam artigos e livros em que são discutidos os principais conceitos e autores da criminologia e da Escola Positiva de Direito Penal.

\subsection{A CRIMINOLOGIA CRÍTICA NO BRASIL}

A criminologia crítica começa a se desenvolver na Europa e na América, na segunda metade do século XX. As teorias da criminologia crítica possuem premissas básicas em comum, mas não representam um pensamento homogêneo.

O imperialismo das duas potências mundiais da época (EUA e URSS) sobre países asiáticos, africanos e americanos, a questão ambiental, os casos envolvendo corrupção de políticos famosos e as ditaduras militares que assolaram o cenário mundial tornaram-se importantes elementos influenciadores das obras criminológicas críticas na época. Nesta seara, a observação empírica dos crimes de colarinho branco (white-collar), das fraudes contra a previdência, dos crimes ambientais, dentre outros, demonstravam que a atuação do sistema penal não se mostrava tão eficiente quanto em relação a outros tipos delituosos, como furto e tráfico de drogas, por exemplo ${ }^{43}$.

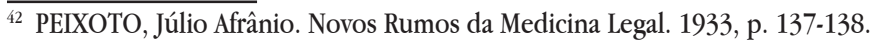

${ }^{43}$ RIBEIRO, Homero Bezerra. A Necessidade de Superação do Paradigma Criminológico Tradicional. 2010, p. 964-965. 
$\mathrm{Na}$ América Latina, em geral, e no Brasil, em particular, as teorias críticas desenvolveram-se como um forte contraponto às ditaduras militares, como se pode ver nas obras de Roberto Lyra Filho (1926-1986), Lola Aniyar de Castro, Rosa del Olmo Pérez-Enciso (1937-2000), Eugenio Raúl Zaffaroni, Juarez Cirino dos Santos (1942), Nilo Batista (1944), Vera Malaguti de Souza Weglinski Batista.

Roberto Lyra Filho, filho do jurista Roberto Lyra (precursor da criminologia cocialista no Brasil), foi um dos precursores no Brasil do pensamento criminológico dialético. De 1963 a 1984, foi professor da Faculdade de Direito da Universidade de Brasília. Em 1972, publicou o livro "Criminologia Dialética" ${ }^{4}$.

É com a obra "Criminologia Dialética" que a criminologia socialista transforma-se e ganha um novo método, afastando-se ainda mais do Direito penal dogmático e, consequentemente da lógica aristotélica. Roberto Lyra Filho aprofunda as noções de contradição e superação, frisando a polarização social e libertando o pensamento de uma visão maniqueísta, bem e mal, dando um conteúdo de classe e permitindo que sejam revelados os interesses que permeiam o processo social. Com esse manancial teórico, consegue-se entender e, principalmente, não esquecer, por que os abolicionistas que eram taxados de criminosos, posteriormente foram consagrados como heróis, permitindo, assim, que se pense nos atuais movimentos, destacadamente o MST, que luta por terra ${ }^{45}$.

Lyra Filho fundou, com outros companheiros, a Nova Escola Jurídica Brasileira $\left(\mathrm{NAIR}^{46}\right)$, cujo boletim era a revista Direito \& Avesso. Segundo o jurista,

Direito é processo, dentro do processo histórico: não é uma coisa feita, perfeita e acabada; é aquele vir-a-ser que se enriquece nos movimentos de libertação das classes e grupos ascendentes e que definha nas explorações e opressões que o contra-dizem, mas de cujas próprias contradições brotarão as novas conquistas. Quando a burguesia, em avanço e subida, desafiou as discriminações aristocrático-feudais ela colocou o problema da igualdade; e quando essa mesma burguesia se encarapitou no poder e negou a igualdade real em suas leis, desencadeando a crítica marxista, que mostrava a fonte

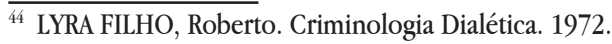

${ }^{45}$ LOPES, Antônio. Teoria Crítica em Roberto Lyra Filho. 2008, p. 134.

${ }^{46}$ Homenagem a Nair Heloisa Bicalho de Sousa que foi uma incentivadora do projeto desde os primeiros momentos. 
das desigualdades, foi a contradição apontada que indicou o caminho para o socialismo; quando o socialismo degenera em opressão burocrático-autoritária, falando em nome duma classe proletária, a que mecanismos estatais negam a real participação no poder, é também esta contradição que gera o movimento para democratizar o "socialismo" implantado, que se deixou engordar em dominação-repressã $0^{47}$.

Roberto Lyra Filho criou uma corrente crítica do pensamento jurídico, intitulada por ele "O Direito Achado na Rua", que "[...] entende que o verdadeiro direito é o que nasce dos movimentos sociais"

Discípulo de Alessandro Baratta ${ }^{49}$, Juarez Cirino dos Santos, professor universitário e advogado, é um dos pioneiros da criminologia crítica no Brasil e atualmente preside o Instituto de Criminologia e Política Criminal. Dentre suas obras, destacam-se "As Raízes do Crime"50, "A Criminologia Radical"51, "A Moderna Teoria do Fato Punível"

Cirino dos Santos considera a criminologia crítica como

produto da integração da teoria do conflito de classes do marxismo, que desenvolveu um modelo de compreensão dos processos objetivos das relações sociais de produção e distribuição da riqueza material, com a teoria da interação social do labeling approach, que desenvolveu um modelo de compreensão dos processos subjetivos de construção social da criminalidade $\mathrm{e}^{54}$.

Em relação ao objeto de estudo da criminologia crítica, Cirino dos Santos divide-o em:

a) a estrutura econômica das relações sociais de produção e distribuição da riqueza material, configurada pela contradição capital/trabalho assalariado; b) o sistema de justiça criminal (lei, polícia, justiça e prisão), bem como o conjunto das

\footnotetext{
${ }_{47}$ LYRA FILHO, Roberto. O Que é Direito. 1990, p. 56.

${ }^{48}$ SOUZA JÚNIOR, José Geraldo de. Direito como Liberdade. 2008, p. 14.

${ }^{49}$ Alessandro Baratta, filósofo, sociólogo e jurista italiano, é considerado um dos percursores da corrente da Criminologia Crítica, além de ter impulsionado a teoria abolicionista e o garantismo penal - direito penal mínimo.

${ }^{50}$ SANTOS, Juarez Cirino dos. As Raízes do Crime. 1984.

${ }^{51}$ Idem, A Criminologia Radical. 2008.

${ }^{52}$ Idem, A Moderna Teoria do Fato Punível. 2005.

${ }^{53}$ Idem, Direito Penal. 2012.

${ }^{54}$ Idem, Os Discursos sobre Crime e Criminalidade. 2013, p. 56, grifo do autor.
} 


\section{instituições jurídicas e políticas do Estado55.}

Quanto ao método, a criminologia crítica, segundo Cirino dos Santos,

trabalha com o método dialético do materialismo histórico, fundado no princípio da contradição de objetos sociais, pelo qual o conflito antagônico da relação capital/trabalbo assalariado das formações sociais capitalistas é o princípio metodológico capaz de explicar as instituições jurídicas e políticas do Estado capitalista e, de modo especial, a criação da lei penal e o funcionamento do sistema de justiça criminal ${ }^{56}$.

Nilo Batista, professor de direito penal brasileiro e advogado, foi governador do Estado do Rio de Janeiro de 02 de abril de 1994 até o fim do mesmo ano, em substituição a Leonel Brizola, que se licenciara para concorrer nas eleições presidenciais. É professor titular de direito penal na Universidade do Estado do Rio de Janeiro (UERJ) e na Universidade Federal do Rio de Janeiro (UFRJ). Na área de criminologia crítica, Nilo Batista é consultor da Coleção "Pensamento Criminológico" e da revista "Discursos Sediciosos", editados pela editora Revan e pelo Instituto Carioca de Criminologia, fundado por ele. Dentre suas obras, destacam-se "Punidos e Mal Pagos"57, "Introdução Crítica ao Direito Penal Brasileiro"58 e "Direito Penal Brasileiro: primeiro volume: Teoria Geral do Direito Penal"59.

A criminologia crítica, para Batista, ao contrário da criminologia tradicional,

[...] não aceita, qual a priori inquestionável, o código penal, mas investiga como, por quê e para quem (em ambas as direções: contra quem, e em favor de quem) se elaborou este código e não outro. A Criminologia Crítica, portanto, não se autodelimita pelas definições legais de crime (comportamentos delituosos), interessando-se igualmente por comportamentos que implicam forte desaprovação social (desviantes). A Criminologia Crítica procura verificar o desempenho prático do sistema penal, a missão que efetivamente lhe corresponde, em cotejo funcional e estrutural com outros instrumentos formais de controle social (hospícios, escolas, institutos de menores, etc.). A Criminologia Crítica insere o sistema

\footnotetext{
55 Ibidem, p. 57, grifo do autor.

${ }^{56}$ Ibidem, p. 58, grifo do autor.

${ }^{57}$ BATISTA, Nilo. Punidos e Mal Pagos. 1990.

${ }^{58}$ Idem, Introdução Crítica ao Direito Penal Brasileiro. 2007.

${ }^{59}$ Idem, Direito Penal Brasileiro. 2003.
} 
penal - e sua base normativa, o direito penal - na disciplina de uma sociedade de classes historicamente determinada e trata de investigar, no discurso penal, as funções ideológicas de proclamar uma igualdade e neutralidade desmentidas pela prática $^{60}$.

Vera Malaguti Batista, mestre em história social (UFF) e doutora em saúde coletiva pelo Instituto de Medicina Social da UERJ, é secretária geral do Instituto Carioca de Criminologia e autora dos livros "Difíceis Ganhos Fáceis: drogas e juventude pobre no Rio de Janeiro" ${ }^{61}$ e "O Medo na Cidade do Rio de Janeiro: dois tempos de uma história" ${ }^{2}$. É, também, consultora da Coleção "Pensamento Criminológico" e da revista "Discursos Sediciosos". Segundo Malaguti Batista,

A criminologia crítica ou aquela que conhece a história do sistema penal (seu fracasso aparente e suas silentes vitórias), foi fértil em produzir projetos coletivos de redução de danos do poder punitivo em seu ápice, mas não conseguiu romper as barreiras que, por exemplo, a luta antimanicomial conseguiu. Mas é que a questão criminal é fundamental para a governamentalidade do capitalismo contemporâneo: trata-se o problema do controle do tempo livre na revolução técnocientífica do capital vídeo-financeiro ${ }^{63}$.

\section{O ESTADO PATRIMONIALISTA E O DIREITO PENAL BRASILEIRO}

Sem abandonar a perspectiva de um direito de classes, buscou-se, na criminologia crítica, uma justificativa mais complexa, que explique a natureza do clientelismo que marca nosso direito penal. Isso porque, além da proteção de classes, que pode ser demonstrada com clareza, uma proteção mais difusa, que afeta a grupos que não se identificam necessariamente com classes sociais, é sentida no direito penal brasileiro. Para entender essa realidade, buscou-se em Faoro o conceito de estamento, para justificar o sistema de dominação que impregna a história brasileira, por meio do exercício de poder por grupos heterogêneos.

A burguesia fortalecida e em franca ascensão, com o início da era das navegações, reúne forças, e, associada ao rei, aplaca, novamente, a nobreza. O Estado

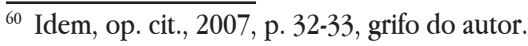

${ }^{61}$ BATISTA, Vera Malaguti. Difíceis Ganhos Fáceis.

${ }^{62}$ Idem, O Medo na Cidade do Rio de Janeiro.

${ }^{63}$ Idem, Introdução Crítica à Criminologia Brasileira. 2011, p. 120.
} 
moderno ganha contornos definidos, e o capitalismo germina na mescla complexa que forma o Estado patrimonialista ${ }^{64}$.

Uma das formas de se explicar o que acontece(u) no Brasil vem de uma visão mais aberta, a partir da qual não se fala em morte, mas em continuidade do regime feudal português, matriz do Estado patrimonialista. Nessa perspectiva as relações entre o homem e o poder não são relações de classes, mas de dominado e dominador, não se sentindo as partes vinculadas à noção de relações contratuais, que ditam limites ao príncipe, um Estado patrimonialista e não feudalista, onde se pode sentir uma ordem burocrática com o soberano sobreposto ao cidadão, na qualidade de chefe para funcionário ${ }^{65}$.

O que Faoro sustenta é a baseada no fato de que o feudalismo não cria um Estado, mas tão somente corporifica um conjunto de poderes políticos, sem que haja uma superposição (definida) de camadas sociais umas sobre as outras, de onde surge, na teoria marxista, a necessidade de ajuste a movimentos sociais e explica a revolução do proletariado.

Isso não se dá no feudalismo que deu origem ao Estado patrimonialista, controlado por estamentos e não por classes. Tal afirmação parte do princípio de que o feudalismo, em primeiro lugar, não ser um fenômeno exclusivamente europeu; em segundo lugar, por não ser uma realidade histórica que pode ser construída mediante modelos arbitrariamente concebidos, sendo composto de elementos militares, econômico-sociais e políticos.

Em um Estado patrimonialista, afirma Faoro, ao contrário do feudalista, "a economia e a administração se conjugam para a conservação da estrutura, velando contra forças desagregadoras, situadas na propriedade territorial, ansiosas de se emanciparem das rédeas tirânicas que lhes impedem a marcha desenvolta" ${ }^{66}$. Assim, a formação da matriz de reprodução da lógica gerencial da filial é a do modelo patrimonialista, como defende Faoro (e não feudal).

De fato os estamentos são grupos mais complexos, heterogêneos, e formados não por possuírem características uniformes, como as classes sociais, mas por possuírem interesses em comum, como gerir o Estado em seu proveito,

\footnotetext{
${ }^{64}$ Faoro menciona duas formas de se explicar a história brasileira. Uma delas partindo da perspectiva marxista, em que uma sociedade feudal em ruínas dá lugar a um modelo exploratório de classes, por meio do monopólio (domínio) do sistema de produção, passando pela mais-valia e pela revolução industrial, em que a reificação do homem faz brotar o capitalismo, filho, como dito, do fracassado feudalismo burguês. FAORO, R. Os Donos do Poder. 2001, p. 34 et seq.

${ }^{65}$ Ibidem, p. 35.

${ }^{66}$ Ibidem, p. 38.
} 
mantendo suas conquistas e assegurando uma forma de exercício de poder. Formamse e transformam-se, assim, sem uma dinâmica previsível, até por não terem uma essência coerente como a das classes sociais.

Curiosamente, o estamento forma-se em Portugal, e no Brasil, de cima para baixo, confundindo-se, por vezes com a nobreza, a burguesia e a administração do príncipe, mas o que de fato acontece é sua constituição como uma máquina burocrática $^{67}$. Faoro afirma que o Estado é "[...] um feixe de cargos, reunidos por coordenação, com respeito à aristocracia dos subordinados" ${ }^{" 68}$, e os estamentos (aristocracia e burguesia), então, convivem pacificamente, mesmo que "[...] num plano subterrâneo, obscuro e incerto: embarcadas na mesma empresa, o fomento das navegações e dos lucros será o fim comum. Separa-os a partilha” ${ }^{{ }^{9}}$. As partes do estamento toleram-se para preservarem-se no poder ou manter sua influência no exercício do poder.

O final do século XIX é marcado no Brasil pelo conflito entre as liberais ${ }^{70}$ e as elites escravagistas e agrárias, enquanto se assiste ao surgimento da vida e da atividade urbana, tendo como pano de fundo uma guerra entre o comércio exterior (fortíssimo) e o interior (incipiente). Enquanto o instrumento de força da classe senhorial era a guarda nacional, o exército era, ao contrário, a carreira dos desafortunados, predominante em determinadas camadas da classe média.

Assim, padres, militares, funcionários e pequenos comerciantes formam o nicho de surgimento e de defesa de novas libertárias, e, como resultado disso, notase paralelamente uma grande demanda pelos serviços públicos, educação, crédito, transportes, formação profissional e financiamento industrial, assuntos "[...] para os quais o Governo Imperial, ainda fortemente influenciado pelos homens ligados aos interesses agrários e escravagistas, nem sempre tinha sensibilidade" ${ }^{71}$.

A população do Rio de Janeiro e dos demais centros urbanos, em virtude do

\footnotetext{
${ }_{67}$ É importante definir burocracia adequadamente, já que por si só não se trata de termo depreciativo, referindo-se ao pessoal necessário para que os atos de gestão se realizem, propiciando inclusive segurança e transparência. É claro que, no caso dos estamentos aqui mencionado, cria-se uma burocracia adequada a um fim próprio, ou seja, a manutenção deles próprios enquanto instâncias gestoras de poder.

${ }^{68}$ FAORO, R. Os Donos do Poder. 2001, p. 102.

${ }^{69}$ Ibidem, p. 91.

${ }^{70}$ Geradoras do iluminismo penal cujos frutos, segundo Batista, apenas aparecem no verniz da escritura do sistema penal de 1830, marcando com sua "grosseira corporalidade" escravos e soldados. (BATISTA, N. Novas tendências do Direito Penal. 2004, p. 33). No mesmo sentido, Marcelo Cerqueira afirma que o liberalismo do século XX serviu apenas aos interesses da elite, principalmente pela manutenção da escravidão. CERQUEIRA, Marcelo. Cartas Constitucionais. 1997, p. 111.

${ }^{71}$ AGUIAR, Pinto de. Rui e a Economia Brasileira. 1973, p. 33.
} 
apogeu da cafeicultura, que levou a um alto índice de imigração, e sua crise, trazendo aumento progressivo do desemprego, paralelamente já não se assujeitava à vida rura $^{2}$. Fica clara a existência de um choque entre as novas forças mencionadas e o modelo do império, reeditado nos princípios da república.

Aqui já há a substituição do latifundiário pelo empresário exportador, que, por sua vez, se transforma no senhor de rendas e produtos, fazendo surgir um clima no qual se manifestava a tendência emancipatória de matizes liberais, formada pelos ventos vindos da Europa, e que efetivamente tinha um "[...] caráter menos doutrinário do que justificador: os ricos e poderosos fazendeiros cuidam em diminuir o poder do rei e dos capitães-generais apenas para aumentar o próprio, numa nova partilha de governo, sem generalizar às classes pobres a participação política"73 (grifo nosso).

O novo rosto do poder, vindo da urbe, torna-se mais bem delineado a cada momento que passa, enquanto a Corte, no Rio de Janeiro, passa por (mais) uma grave crise, a de libertar-se do período colonial, sem, contudo, pôr fim ao regime monárquico, em uma sociedade extremamente desigual, formada por colonos, e a uma aristocracia constituída basicamente pela burocracia estatal ${ }^{74}$. Isso durante um período em que a economia migra de um sistema extrativista puro e simples para um capitalismo pseudoliberal, que buscava uma emancipação econômica sui generis ${ }^{75}$.

Naquele momento em especial, os estigmas penais se mostram eficientes sustentáculos de um "[...] discurso racista legitimador da hegemonia, e do positivismo jurídico, que confinava o olhar à articulação lógica dos parágrafos e incisos. [...] o mito da ressocialização para o trabalho edifica colônias agrícolas e estabelecimentos penais industriais. Finalmente haviam chegado os tempos modernos"76.

O retrato do Brasil, então, é o retrato da república e suas circunstâncias, e em especial no Rio de Janeiro, então Capital Federal, que vive um clima social tenso e complexo, agravado por uma série de fatores como inflação, desemprego, marginalização, formação de uma classe dominante de maneira complexa e intrincada, com militares ascendentes (depois de um período de extremo desprestígio), escravos

\footnotetext{
${ }^{72}$ Ibidem, p. 34-40.

${ }^{73}$ FAORO, R. op. cit., p. 283.

74 "O eixo da política era o mesmo, secularmente fundido: o reino deveria servir à camada dominante, ao seu desfrute e gozo. Os fidalgos ganharam pensões, acesso aos postos superiores os oficiais da Armada e do Exército, empregos e benefícios os civis e eclesiásticos". FAORO, R. Os Donos do Poder. 2001, p. 289.

75 É importante lembrar que a emancipação sobre a qual se fala é da colônia, que, embora tenha agora a sede da monarquia em suas terras, ainda não é Estado livre, nem econômica, nem politicamente falando.

${ }^{76}$ BATISTA, Nilo. Novas Tendências do Direito Penal. 2004, p. 112.
} 
recém-libertos e uma migração urbana acentuada ${ }^{77}$. Os centros urbanos mostram-se eficientes na empreita de excluir aqueles que não fazem parte da sociedade e que se aglomeram, sem muita perspectiva de crescimento. Apesar disso, pouco antes da Proclamação da República, que antecede o Código Penal de 1890, o enfraquecimento das monoculturas, o urbano tropismo e o desgaste do regime monárquico pedem um novo tipo de Estado emergente.

A República, assim, para se sustentar, precisava contar, mesmo que de forma aparente, com o respaldo e a participação popular, nos moldes da Revolução Francesa. Em suma, era importante que o povo, mesmo que formalmente, protagonizasse um papel de relevo no novo regime, para dar-lhe credibilidade, mas não havia o menor interesse que houvesse uma efetiva participação popular na deliberação do futuro da República.

Era necessário um novo regime que proporcionasse a inclusão da grande massa, agora ocupando as cidades, onde se acumulavam em torno da miséria repartida entre muitos. Na verdade as mudanças que "[...] vinham fermentando durante os últimos anos do império e que culminaram na abolição da escravidão e na proclamação da República [...]"78 geraram um período conturbado nos centros urbanos em fase de formação.

A época era turbulenta e as transformações "[...] de natureza econômica, social, política e cultural, que gestavam há algum tempo, precipitaram-se com a mudança de regime [...]"79. Tal agitação durou a primeira década da República e deu contornos claros ao direito penal que nasce quase ao mesmo tempo. Neste contexto, a população urbana ganha rapidamente um grande volume de desempregados e de subempregados, com a abolição da escravatura. Somando-se a isso, o crescimento populacional dos novos pobres dava ao Rio de Janeiro a fama de ser uma cidade "[...] cheia de gatunos e malfeitores de todas as espécies" ${ }^{\text {. }}$.

E assim vão formando-se os estigmas que constroem a imagem de uma população, excluída pela falta de educação, preparo, formação de qualquer tipo, rejeitada por ser composta do que se poderia comparar

\footnotetext{
77 Carvalho afirma, citando o manifesto do centro socialista aos operários e proletários, de 9 de janeiro de 1899, lançado no Rio de Janeiro, que enquanto o Império viveu sob o domínio dos senhores de escravos, a República vive em torno de sindicatos políticos e industriais, em uma perigosa plutocracia, tão nociva quanto a antiga aristocracia. CARVALHO, José Murilo de. Os Bestializados. 1987, p. 56.

${ }^{78}$ CARVALHO, José Murilo de. Os Bestializados. 1987, p. 16.

${ }^{79}$ Ibidem, p. 15.

${ }^{80}$ Assim é descrita a horda de desempregados que povoavam as ruas do Rio, pelo embaixador português. Ibidem, p. 18, grifo nosso.
} 
[...] às classes perigosas ou potencialmente perigosas de que se fala na primeira metade do século XIX. Eram ladrões, prostitutas, malandros, desertores do Exército, da Marinha e dos navios estrangeiros, ciganos, ambulantes, tropeiros, criados, serventes de repartições públicas, ratoeiros, recebedores de bondes, engraxates, carroceiros, floristas, bicheiros, jogadores, receptadores, pivetes (a palavra já existia) ${ }^{81}$.

O retrato da marginália, de que a sociedade de bem, proprietária da República, deveria se defender está se formando. Também foi um período marcado por especulações financeiras e inflação, e somava-se a isso o fato de os militares buscarem o prestígio perdido e do qual sentiam falta ${ }^{82}$, por haverem "[...] provado o poder que desde o início da Regência lhes fugira das mãos" ${ }^{\text {83 }}$. Murilo de Carvalho procura deixar claro que o vínculo entre militares e civis se dava com certa facilidade, já que seus interesses não se alinhavam aos do grande comércio e da grande agricultura.

Nesse meio tempo, os operários e os pequenos proprietários, empregados e funcionários públicos, detentores de pouco patrimônio, com seus ganhos erodidos pela inflação, tentavam organizar-se, em constante conspiraçã $0^{84}$. Para caracterizar a matriz ideológica do momento recorre-se novamente a Murilo de Carvalho, que afirma não terem sido produzidas na república correntes ideológicas próprias, embora houvesse um abrir de janelas, permitindo uma mescla de vindas da Europa, "[...] sem muita preocupação ideológica ou substantiva [...]"85.

Por outro lado, como reflexo da República notou-se nas elites uma sensação geral de liberdade, em especial no que se refere a padrões de bonestidade e de moral, uma vez que a saída do velho imperador teria, simbolicamente, significado a emancipação dos filhos, gerando uma sede de enriquecimento a qualquer custo ${ }^{86}$, para uma pequena elite dominante que via na República o sinônimo de riqueza. Naquele clima, "[...] se deu uma vitória do espírito do capitalismo desacompanhado

${ }^{81}$ CARVALHO, José Murilo de. Os Bestializados. 1987, p. 18.

${ }^{82}$ No Brasil, os militares, ao profissionalizarem-se, como atrativo à carreira, alcançaram de certa forma o status de nobreza, conforme menciona Faoro. Os militares ganham status no século XVII, é o meio de se integrar o colono à ordem metropolitana. "A patente embranquece e nobilita: ela está no lugar da carta de bacharel, no Império". FAORO, R. Os Donos do Poder. 2001, p. 223, grifo nosso.

${ }^{83}$ CARVALHO, José Murilo de. op. cit., p. 22. Acrescenta José Murilo que daí vem o fato de julgarem-se salvadores da república.

${ }^{84}$ Ibidem, p. 22-23.

${ }^{85}$ Ibidem, p. 24. Cita o liberalismo (de Spencer a Alberto Sales), o positivismo, o socialismo e o anarquismo.

${ }^{86}$ Ibidem, p. 26. 
da ética protestante" ${ }^{" 77}$.

Era então o Brasil um "país de baixo consumo, de escassa produtividade no trabalho, de renda mal distribuída, destituído de possibilidades de acúmulo de capital, pobre de recursos técnicos e científicos, cujos rumos da economia eram decididos no mais das vezes pelos países ricos de poupança e de técnica, através de seus banqueiros e investidores" ${ }^{\prime 8}$.

O direito então, já com o velado interesse de dominação/manutenção de poder, dava as mãos à medicina social ${ }^{89}$, que buscava vincular o bomem a doenças, mais especificamente às ligadas às camadas desfavorecidas da sociedade, como se o crime fosse resultado de um mal contagioso, estigma que marca a revolta da vacina ${ }^{90}$, evento cercado de demonstrações de força e superioridade moral da elite republicana. Nilo Batista afirma que "o positivismo criminológico, tanto quanto a política criminal acoplada às suas premissas, produzia um discurso estratégico para aquela conjuntura, no qual a perdida inferioridade jurídica, inerente às dominações escravagistas, era substituída por uma inferioridade biológica, de base racial"'1.

Assim, sob tal perspectiva, pode-se afirmar que se construiu um direito pena $^{92}$, que funciona como freio regulador estamental, cumprindo a tarefa de assegurar o exercício de poder (ilegítimo ${ }^{93}$, com base no conceito de positivismo legalista da absoluta correspondência da lei ao direito. Tal direito anda paralelo à forma de se exercer o domínio patrimonialista do Estado, emparelhando-se ao

${ }^{87}$ Ibidem, p. 26. Afirma que aqui nasce "[...] um capitalismo predatório fruto típico do espírito dos bandeirantes [...], [quando] o que antes era feito com discrição, ou mesmo escondido para fugir à vigilância dos olhos imperiais, agora podia ser gritado das janelas ou dos coches, era quase um motivo de orgulho pessoal e de prestígio público". Ibidem, p. 27.

${ }^{88}$ AGUIAR, Pinto de. Rui e a Economia Brasileira. 1973, p. 52.

${ }^{89}$ Batista afirma que o saber médico e o saber jurídico se uniram, mesmo sob a forma mais tosca de gestão policial urbana, tendo no paradigma etiológico seu apogeu. BATISTA, Nilo. Novas Tendências do Direito Penal. 2004, p. 12.

${ }^{90}$ Nesse sentido conferir em Ibidem, p. 11, e CARVALHO, José Murilo de. op. cit., passim.

${ }^{91}$ BATISTA, Nilo. op. cit., p. 11.

92 Direito Penal que, segundo Batista, possui a privação de liberdade como pena por excelência, como em toda sociedade industrial (Ibidem, p. 112). Verificou-se, em Pierangeli, as penas citadas para demonstrar o casamento de um direito que, sob o pretexto de ressocializar, angariava mão de obra para a indústria. $\mathrm{O}$ Código Penal dos Estados Unidos do Brasil previa a pena de prisão disciplinar em seu artigo 43, inciso "e", e poderia ser aplicada aos menores de 21 anos, segundo o artigo 49. O que impressiona é a idade mínima para a internação. A vadiagem, prevista no artigo 399, era punida com prisão celular que variava de quinze a trinta dias, mas, segundo o parágrafo segundo do mesmo artigo, "Os maiores de 14 anos serão recolhidos a estabelecimentos disciplinares industriais, onde poderão ser conservados até a idade de 21 anos"; indo além, em seu artigo 30, tem-se que "os maiores de 9 anos e menores de 14, que tiverem obrado com discernimento, serão recolhidos a estabelecimentos disciplinares industriais, pelo tempo que o juiz parecer, contanto que o recolhimento não exceda á idade de 17 anos". PIERANGELLI, José Henrique. Códigos Penais do Brasil. 2009, passim.

93 FAORO, R. Os Donos do Poder. 2001, p. 62. 
movimento dominante (no sentido de ser o que exerce um grau considerável de domínio na administração), seja ele o extrativismo, o escravagismo, a pecuária, o mercantilismo etc., assujeitando os que não participam das elites ${ }^{94}$.

A partir da questão: quem é o destinatário (ou a clientela preferencial) do dDireito penal: doutrina, lei, mídia e opinião pública e o velamento das razões que elevam os indivíduos à condição de selecionados penalmente, valemo-nos de Cirino, que, no capítulo IV da Criminologia Radical, faz uma aproximação entre sistema penal, como um todo, e sistema de produção capitalista. Isso porque o resultado final do controle social, a sanção concreta, é visível em razão do número de presos, proporcional às necessidades e às conveniências do mercado de trabalho, em que a efetividade em grande volume das penas restritivas de liberdade seria uma das formas de "extinção da mão de obra excedente no mercado".

Pode-se afirmar, então, que a retração do movimento punitivo é reflexo da necessidade de mão de obra no mercado. Ressalte-se que o mercado está carente de mão de obra. Hoje, entretanto, a feição do controle social assume caráter mais político e excludente, como forma de controle de massas e repressão legal, porém um pouco mais desligado diretamente da demanda de mão de obra, abundante pelo volume ascendente do proletariado. Garcia afirma que

O Direito Penal patina. A primeira das peculiaridades que nos salta à vista no sistema progressivo brasileiro é, por certo, o fato de que se caminha, no Brasil, para a limitação, tanto quanto possível, da cela ou célula. Deixou-se influenciar o legislador brasileiro de 1940 pelo movimento anti-celular de que é legenda a famosa frase de Ferri, sempre repetida: "a cela é uma das aberrações do século XIX". ${ }^{95}$

O conflito de classes tornou-se iminente no Brasil, e os muros divisórios entre os cidadãos de "bens" e os demais já não estão sendo capazes de conter as massas. Assim, o foco do jogo de poder do sistema penal está mais dirigido para o controle e a disciplina ${ }^{96}$ do proletariado, que assume uma posição de submissão e de cidadãos de terceira classe, prontos para o processo de sujeição inerente ao sistema de exploração de classes. A docilização dos corpos torna-se útil, e o exemplo, opção

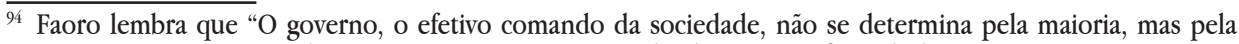
minoria que, a pretexto de representar o povo, o controla, deturpa e sufoca. Ibidem, p. 109.

${ }^{95}$ GARCIA, Basileu. Instituições de Direito Penal. 1954, p. 428.

96 SANTOS, Juarez Cirino dos. A Criminologia Radical. 2008, p. 44.
} 
por uma conduta anormal bastante dissuasiva. Além disso, pode-se dizer que "[...] as casas panópticas ${ }^{97}$ de confinamento eram antes e acima de tudo fábricas de trabalbo disciplinado" ${ }^{98}$.

\section{CONSIDERAÇÕES FINAIS}

Deve-se lembrar que a questão da quantidade e da qualidade da doutrina e da produção científica em criminologia dessa formação social relacionam-se, por sua vez, à extensão e à profundidade dos problemas sociais presentes nesse quadro real, especialmente os relativos ao crime e ao desvio, e às formas indicadas para sua prevenção ou redução $0^{99}$.

O fato é que no Brasil contemporâneo o controle social na esfera penal além de mostrar-se claramente ineficiente carece, também, de fundamentação a partir do modelo constitucional, social, plural e democrático, com a clara e expressa opção pelo garantismo e humanismo. As marcas das dinâmicas seletivas mostramse presentes desde os processos de criminalização até as dinâmicas preventivas, repressivas, judiciais e prisionais, obstaculizando um grau mínimo de contenção ou de controle da violência social que se experimenta diuturnamente.

Mesmo assim é necessário lembrar que em qualquer núcleo social complexo, por mais simples que se apresente, a proposta de que os desvios do sistema penal são resultados exclusivos da luta de classes é reducionista. As ideologias de fato assumem uma função de ocultação dos reais interesses em jogo, que envolvem, na verdade, interesses bem mais complexos ${ }^{100}$. Ainda nesse sentido, Bobbio afirma que

al tema de la visibilidad e invisibilidad del poder se suman otros dos temas: el de la ideología como ocultación y el de la creciente capacidad para conocer los comportamientos de los ciudadanos, y portante "verlos" a través de la organización pública de centros de información cada vez más perfeccionados y siempre más eficazes mediante la utilización de medios

\footnotetext{
${ }_{97}$ Segundo o filósofo e jurista Jeremy Bentham (1748-1832), o Panóptico é um instrumento de inspeção: um edifício com arquitetura e arranjos estilísticos únicos, cujo objetivo primeiro é aplicar os pressupostos do utilitarismo em situações onde certos indivíduos necessitem estar sob contínua e cautelosa verificação.

98 BAUMAN, Zygmunt. Globalização: as consequências humanas. Trad. Marcus Penchel. Rio de Janeiro: Jorge Zahar, 1999. p. 117, grifo do autor.

${ }^{99}$ SANTOS, Juarez Cirino dos. A Criminologia da Repressão.1979, p. 77.

${ }^{100}$ Ocultação na perspectiva heideggeriana, como na metáfora da clareira.
} 
electrónicos.[Diz, ademais, que] una de las funciones de la ideología es la de ocultar la verdad como objeto de dominio ${ }^{101}$.

Preferiu-se adotar uma visão mais complexa como a de Faoro ao falar do domínio de estamentos (e não simplesmente de classes), conceito mais complexo e naturalmente mais apto a explicar todo o sistema de dominação, em especial quando há referência a seu aspecto jurídico, no qual os metadiscursos buscam reafirmar um semema que já não se sustenta de forma autônoma.

De maneira recorrente, buscam-se fundamentos no sistema de controle social nas antigas fontes que nos levam a grupos, classes e indivíduos perigosos. Recupera-se a ideia moderna do combate ao risco na busca de evitar o inevitável, terceirizando a interdição, temendo o outro e cedendo mais e mais direitos ao Estado que cresce na figura paternalista despótica do grande irmão que a tudo vê e a todos controla. Mais Estado, mais intervenção não são sinônimos de mais segurança. Garantia não se opõe a eficiência. O papel do indivíduo como o grande culpado é o álibi necessário para um Estado com maior grau de intervenção e como gestor de morais e valores.

$\mathrm{Na}$ verdade, enquanto não se define com clareza objetos e objetivos do sistema de controle social na esfera penal e seus diversos braços (ou agências) é impossível construir políticas criminais legítimas e fundamentadas a partir dos parâmetros constitucionais eleitos como norteadores de sentido do projeto civilizatório que se pretende constituir. Assim, a questão essencial para que se defina o grau de legitimidade de um modelo penal é descobrir para que serve (ou a quem serve) o direito penal, finalidade esta que acaba por confundir-se com finalidade da pena $^{102}$.

A produção penal (doutrinária e positiva, necessariamente coordenadas) deve assumir o caráter (pro)posto pela Constituição Federal, que convoca um sistema sancionador positivo, diferente do paradigma liberal individual, já que destinado a uma sociedade plural e fraterna, que tem como matriz o Estado social democrático de direito, destinada ao bem-estar ${ }^{103}$ do indivíduo, visto como fim do Estado e não meio para a consecução de fins outros.

A proposta de um direito posto para resolver os mais diversos (ou todos)

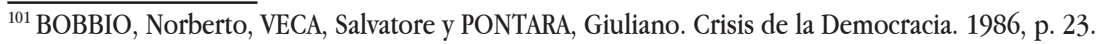

${ }^{102}$ BATISTA, Nilo. Introdução Crítica ao Direito Penal Brasileiro. 2007, p. 111.

${ }^{103}$ Bem-estar como conceito complexo que envolve as mais diversas condições e possibilidades e estar dignamente no mundo.
} 
problemas das mais diversas naturezas deve ser superado, pois este não é nem pode ser o fim do direito. Nesse sentido, é bom lembrar que a importância da questão é crucial, já que, como afirma Bettiol, quando o Estado cuida do retrato de uma sociedade individualista, que se despedaça em uma miríade de identidades fugidas, autocentradas, narcisistas, em estado de insegurança total, estas são o retrato do discurso penal ${ }^{104}$. O direito penal do risco provém de um discurso narcisista, uma vez que se propõe a tudo resolver ${ }^{105}$.

\section{REFERÊNCIAS}

ABREU, Maria Aparecida Azevedo. Raimundo Faoro: quando mais é menos. Perspectivas, São Paulo, SP, v. 29, p. 169-189, 2006.

AGUIAR, Pinto de. Rui e a Economia Brasileira. Rio de Janeiro, RJ: Fundação Casa de Rui Barbosa, 1973.

ALVAREZ, Marcos César. A Criminologia no Brasil ou Como Tratar Desigualmente os Desiguais. DADOS - Revista de Ciências Sociais, Rio de Janeiro, RJ: IUPERJ, v. 45, n. 4, p. 677-704, 2002.

ALVES, Giovanni. Terceira Modernidade do Capital, Crise de Civilização e Barbárie Social. 2011. Disponível em: <http://boitempoeditorial.wordpress. com/2011/09/26/terceira-modernidade-do-capital-crise-de-civilizacao-e-barbariesocial/> . Acesso em: 16jan. 2016.

ALVES, Giovanni. Dimensões da Reestruturação Produtiva: ensaios de sociologia do trabalho. Londrina; Bauru: Praxis; Canal 6, 2007.

BARATTA, Alessandro. Criminologia Crítica e Crítica do Direito Penal: introdução à sociologia do Direito Penal. 2. ed. Rio de Janeiro, RJ: Freitas Bastos, Instituto Carioca de Criminologia, 1999.

BARRETO, Tobias. Menores e Loucos em Direito Criminal. Edição fac-similar. Brasília, DF: Senado Federal, Conselho Editorial, 2003.

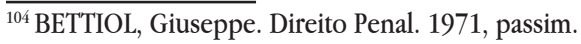

${ }^{105}$ GLOECKNER, Ricardo Jacobsen. Risco e Processo Penal. 2009, p. 151.
} 
BATISTA, Nilo. Punidos e Mal Pagos. Rio de Janeiro, RJ: Revan, 1990.

BATISTA, Nilo. Novas Tendências do Direito Penal: artigos, conferências e pareceres. Rio de Janeiro, RJ: Revan, 2004.

BATISTA, Nilo. Introdução Crítica ao Direito Penal Brasileiro. 11. ed. Rio de Janeiro, RJ: Revan, 2007.

BATISTA, Nilo; ZAFFARONI, Eugenio Raúl; ALAGIA, Alejandro; SLOKAR, Alejandro. Direito Penal Brasileiro: primeiro volume: Teoria Geral do Direito Penal. Rio de Janeiro, RJ: Revan, 2003.

BATISTA, Vera Malaguti. Difíceis Ganhos Fáceis: drogas e juventude pobre no Rio de Janeiro. 2. ed. Rio de Janeiro, RJ: Revan, 2009.

BATISTA, Vera Malaguti. O Medo na Cidade do Rio de Janeiro: dois tempos de uma história. 2. ed. Rio de Janeiro, RJ: Revan, 2009.

BATISTA, Vera Malaguti. Introdução Crítica à Criminologia Brasileira. Rio de Janeiro, RJ: Revan, 2011.

BAUMAN, Zygmunt. Globalização: as consequências humanas. Trad. Marcus Penchel. Rio de Janeiro, RJ: Jorge Zahar, 1999.

BETTIOL, Giuseppe. Direito Penal: parte geral. 7. ed. São Paulo, SP: Revista dos Tribunais, 1971. vol. II.

BEVILÁCQUA, Clóvis. Criminologia e Direito. Salvador, BA: Livraria Magalhães, 1896.

BOBBIO, Norberto; VECA, Salvatore; PONTARA, Giuliano. Crisis de la Democracia. Barcelona: Ariel, 1986.

CARVALHO, José Murilo de. Os Bestializados: o Rio de Janeiro e a República que não foi. 3. ed. São Paulo, SP: Companhia das Letras, 1987.

CASTRO, Lola Aniyar de. A Evolução da Teoria Criminológica e Avaliação de seu 
Estado Atual. Revista de Direito Penal e Criminologia, Rio de Janeiro, RJ: Instituto de Ciências Penais do Rio de Janeiro, no 34, p. 71-92, jul./dez., 1982.

CERQUEIRA, Marcelo. Cartas Constitucionais: império, república e autoritarismo, ensaio, crítica e documentação. Rio de Janeiro, RJ: Renovar, 1997.

CYPRESTE, Artur Dalla. Crime e Trabalho no Brasil: o controle das drogas entre a Primeira República e o Código Penal de 1940. 2010. Dissertação (Mestrado em Sociologia Política) - Universidade Estadual do Norte Fluminense, Programa de Pós Graduação em Sociologia Política, Campos dos Goytacazes, RJ, 2010.

FAORO, Raymundo. Os Donos do Poder: formação do patronato político brasileiro. 3. ed. rev. São Paulo, SP: Globo, 2001.

FRAGOSO, Heleno Cláudio. Lições de Direito Penal. Parte Geral. 15 ed. atual. Rio de Janeiro, RJ, Forense, 1995

GARCIA, Basileu. Instituições de Direito Penal. 4. ed. rev. e atual. São Paulo, SP: Max Limonade, 1954. vol. I, tomo II.

GLOECKNER, Ricardo Jacobsen. Risco e Processo Penal: uma análise a partir dos direitos fundamentais do acusado. Salvador, BA: JusPODIUM, 2009.

LEMOS, Clécio José Morandi de Assis. Sistema Penal como Instrumento Proletário: aluta da Criminologia Radical e a legitimação inversa do sistema punitivo. Revista da. Faculdade de Direito da UFMG, Belo Horizonte, MG, n. 63, p. 61-90, jul./dez. 2013.

LESSA, Sérgio; TONET, Ivo. Introdução à Filosofia Marxista. 2. ed. São Paulo, SP: Expressão Popular, 2011.

LIMA, Odilardo Gonçalves. Estrutura Constitucional da Segurança Pública no Brasil. 2005. Dissertação (Mestrado em Direito) - Universidade da Amazônia, Belém, PA.

LOPES, Antônio. Teoria Crítica em Roberto Lyra Filho: uma aproximação dialética e pluralista. 2008. Dissertação (Mestrado em Direito) - Universidade Federal de Santa Catarina, SC. 
LYRA, Roberto (Org.). A Obra de Sylvio Romero em Criminologia e Direito Criminal. Seleção e Dicionário de Pensamentos. Rio de Janeiro, RJ: Nacional do Direito, 1951.

LYRA, Roberto. Novo Direito Penal. Rio de Janeiro, RJ: Forense, 1980

LYRA, Roberto; ARAÚJO JÚNIOR, João Marcello de. Criminologia. 4. ed. Rio de Janeiro, RJ: Forense, 1995.

LYRA FILHO, Roberto. Criminologia Dialética. Rio de Janeiro, RJ: Borsoi, 1972.

LYRA, Roberto. O Que é Direito. 11. ed. São Paulo, SP: Brasiliense, 1990.

LYRA, Roberto. Contribuição à Crítica da Economia Política. 2. ed. São Paulo, SP: Expressão Popular, 2008.

MASCARO, Alysson Leandro. Introdução à Filosofia do Direito: dos modernos aos contemporâneos. São Paulo, SP: Atlas, 2002.

MASCARO, Alysson Leandro. Introdução ao Estudo do Direito. 4. ed. São Paulo, SP: Atlas, 2013.

PEIXOTO, Júlio Afrânio. Novos Rumos da Medicina Legal. Rio de Janeiro, RJ: Guanabara, 1933.

PEREIRA, Francisco. Karl Marx e o Direito: elementos para uma crítica marxista do direito. Salvador, BA: LeMarx, 2015.

PEREIRA, Henrique Viana; MAGALHÃES, Rodrigo Almeida. A Influência da Economia no Direito Penal. Juris Plenum, Caxias do Sul, RS, v. 44, p. 49-61, 2012.

PIERANGELLI, José Henrique. Códigos Penais do Brasil: evolução histórica. 2. ed. São Paulo, SP: Revista dos Tribunais, 2009.

POLAINO, Celso Gomes. Adequação da Pena: reflexões e sugestões. 2011. Dissertação (Mestrado em Direito) - Universidade de São Paulo, São Paulo, SP. 
RIBEIRO, Homero Bezerra. A Necessidade de Superação do Paradigma Criminológico Tradicional: a Criminologia Crítica como alternativa à ideologia da "Lei e Ordem". ENCONTRO NACIONAL DO CONPEDI, 19., Fortaleza, CE. Anais... Fortaleza: CONPEDI, 2010, p. 951-979.

RUSCHE, Georg; KIRCHHEIMER, Otto. Punição e Estrutura Social. Tradução de Gizlene Neder. 2. ed. Rio de Janeiro, RJ: Revan, 2004.

SANTOS, Bartira Macedo de Miranda. As Ideias de Defesa Social no Sistema Penal Brasileiro: entre o garantismo e a repressão (de 1890 a 1940). 2010. Tese (Doutorado em História da Ciência) - Pontifícia Universidade Católica de São Paulo, São Paulo, SP.

SANTOS, Juarez Cirino dos. A Criminologia da Repressão: uma crítica ao positivismo em criminologia. Rio de Janeiro, RJ: Forense, 1979.

SANTOS, Juarez Cirino dos. As Raízes do Crime: um estudo sobre as estruturas e as instituições da violência. Rio de Janeiro, RJ, Forense, 1984.

SANTOS, Juarez Cirino dos. A Criminologia Crítica e a Reforma da Legislação Penal. In: CONFERÊNCIA NACIONAL DOS ADVOGADOS, 19., Florianópolis, SC. Anais... Florianópolis, set. 2005.

SANTOS, Juarez Cirino dos. A Moderna teoria do fato punível. 4. ed. Rio de Janeiro, RJ; Curitiba, PR: Lumen Juris; ICPC, 2005.

SANTOS, Juarez Cirino dos. A Criminologia Radical. 3. ed. Rio de Janeiro, RJ; Curitiba, PR: Lumen Juris; ICPC, 2008.

SANTOS, Juarez Cirino dos. Direito Penal: Parte Geral. 5. ed. Curitiba, PR; Florianópolis, SC: ICPC; Conceito, 2012.

SANTOS, Juarez Cirino dos. Os Discursos sobre Crime e Criminalidade. Revista Judiciária do Paraná, Curitiba, PR, AMAPAR, ano VIII, nº 6, p. 41-62, nov. 2013.

SCHWARCZ, Lilia Katri Moritz. Quando a desigualdade é diferença: reflexões sobre antropologia criminal e mestiçagem na obra de Nina Rodrigues. Gazeta Médica da Bahia, Salvador, BA, n. 76. Supl. 2, 2006. 
SOUZA JÚNIOR, José Geraldo de. Direito como Liberdade: o Direito Achado na Rua - experiências populares emancipatórias de criação do direito. 2008. Tese (Doutorado em Direito) - Faculdade de Direito da Universidade de Brasília, Brasília, DF, 2008.

STUCKA, Petr Ivanovich. Direito e Luta de Classes: teoria geral do direito. São Paulo, SP: Acadêmica, 1988.

TAYLOR, Ian; WALTON, Paul; YOUNG, Jock. The New Criminology: for a social theory of deviance. New York, Harper and How, 1974.

ZAFFARONI, Eugenio Raúl. En Busca de las Penas Perdidas: deslegitimación y dogmática jurídico-penal. Buenos Aires: Ediar, 1998.

ZAFFARONI, Eugenio Raúl. A Palavra dos Mortos: conferências de criminologia cautelar. São Paulo, SP: Saraiva, 2012.

Recebido em: 14 de maio de 2017 Aceito em: 01 de novembro de 2017 